\title{
Pemanfaatan Ekstrak Kulit Buah Manggis (Garcinia mangostana L.) sebagai Pewarna Alami Jaringan Daun dan Batang Krokot (Portulaca oleracea L.)
}

\author{
Gita Fitriyani, Muachiroh Abbas, Siti Samiyarsih \\ Faklutas Biologi Universitas Jenderal Soedirman \\ Jalan dr. Soeparno 63 Purwokerto 53122 \\ Email : gitafitriya97@gmail.com
}

Rekam Jejak Artikel:

Received : 29/08/2019 Accepted : 07/04/2020

\begin{abstract}
Natural dyes are an alternative to synthetic dyes because they are safe, inexpensive and environmentally friendly. natural dye sources obtained from plant parts such as fruit peels. Efforts to use mangosteen rind waste as an herbal remedy can also be used as a natural dye because it has a high enough anthocyanin content. Anthocyanins in mangosteen peel can be obtained through extraction. Maceration is an easy extraction method where the results are only affected by the type of solvent and the extraction time. Purslane (Portulaca oleracea L.) is used as research material because currently purslane has been widely used because of its nutritional content including high metabolic and antioxidant regualting substances. This study aims to determine the ability of mangosteen rind extract in coloring the leaf and stem tissue of purslane, and to determine the type of solvent and optimal immersion time to produce mangosteen rind extract so that it can color the leaf tissue and stems purslane well. The study was conducted experimentally using a Completely Randomized Design (CRD) with 2 factors: factor 1 was the type of solvent using ethanol $96 \%$ and citric acid $14 \%$, the second factor was immersion time, namely 26,27 and 28 hours. The data obtained were analyzed descriptively qualitatively including the contrast and clarity of the preserved tissue preparation of leaf and stem purslane. The results showed mangosteen rind extract has the ability to dye leaf tissue and stems. The type of $14 \%$ citric acid solvent with 28 hours soaking time was optimal in producing mangosteen rind extract so that it was able to dye the leaf and stem tissue of purslane.
\end{abstract}

Keywords: anthocyanin, maceration, mangosteen rind, natural coloring, purslane

\section{Abstrak}

Pewarna alami menjadi alternatif pengganti pewarna sintetis dikarenakan bersifat aman, murah dan ramah lingkungan. Sumber pewarna alami diperoleh dari bagian-bagian tumbuhan misalnya kulit buah. Upaya pemanfaatan limbah kulit buah manggis selain sebagai obat herbal dapat dimanfaatkan juga sebagai pewarna alami karena memiliki kandungan antosianin yang cukup tinggi. Antosianin dalam kulit buah manggis dapat diperoleh melalui ekstraksi. Maserasi merupakan metode ekstraksi yang mudah dilakukan dimana hasilnya hanya dipengaruhi oleh jenis pelarut dan lama ekstraksi. Krokot (Portulaca oleracea L.) digunakan sebagai bahan penelitian karena saat ini krokot telah banyak dimanfaatkan karena kandungan gizi diantaranya mengandung zat pengatur metabolisme dan antioksidan tinggi. Penelitian ini bertujuan untuk mengetahui kemampuan ekstrak kulit buah manggis dalam mewarnai jaringan daun dan batang krokot, dan untuk mengetahui jenis pelarut dan waktu perendaman yang optimal untuk menghasilkan ekstrak kulit buah manggis sehingga dapat mewarnai jaringan daun dan batang krokot dengan baik. Penelitian dilakukan secara eksperimen menggunakan Rancangan Acak Lengkap (RAL) dengan 2 faktor yaitu faktor 1 adalah jenis pelarut menggunakan etanol 96\% dan asam sitrat 14\%, faktor ke 2 lama perendaman, yaitu 26, 27 dan 28 jam. Data yang diperoleh dianalisis secara deskriptif kualitatif meliputi kekontrasan dan kejelasan preparat awetan jaringan daun dan batang krokot. Hasil penelitian menunjukkan ekstrak kulit buah manggis memiliki kemampuan dalam mewarnai jaringan daun dan batang krokot. Jenis pelarut asam sitrat $14 \%$ dengan lama perendaman selama 28 jam merupakan yang optimal dalam menghasilkan ekstrak kulit buah manggis sehingga mampu mewarnai jaringan daun dan batang krokot.

Kata kunci : antosianin, krokot, kulit buah manggis, maserasi, pewarna alami.

\section{PENDAHULUAN}

Pewarnaan berfungsi untuk mewarnai jaringan yang dapat memperjelas bagian-bagian jaringan tumbuhan (Gresby, 2013). Pewarna yang biasa digunakan adalah pewarna sintetis contohnya safranin yang bersifat karsinogenik, harganya mahal dan limbah yang dihasilkan dapat menyebabkan pencemaran lingkungan. Oleh karena itu, harus ada alternatif pengganti pewarna sintetis, yaitu dengan menggunakan pewarna alami yang lebih efisien, harganya murah, memiliki daya afinitas tinggi dan aman. Pewarna alami merupakan pewarna yang 
tidak toksik dan ramah lingkungan. Pewarna alami dapat diperoleh melalui proses ekstraksi dari bagianbagian tumbuhan seperti : bunga, buah, daun, biji, kulit, batang/kayu dan akar tumbuhan (Pujilestari, 2015).

Peningkatan produksi buah manggis di Indonesia menyebabkan peningkatan limbah kulit buah manggis (Rubiyanti et al., 2014). Salah satu pemanfaatan limbah kulit buah manggis yaitu sebagai suplemen herbal untuk mengobati penyakit diantaranya diare, sariawan, nyeri urat dan sembelit (Puspitasari et al., 2016). Selain dimanfaatkan sebagai obat herbal limbah kulit buah manggis dapat dimanfaatkan sebagai pewarna alami karena mengandung kadar antosianin yang cukup tinggi yaitu sebesar 593 ppm (Farida \& Nisa, 2015). Ekstrak kulit buah manggis selain digunakan sebagai pewarna makanan, minumam, pewarna logam dan pewarna kain, juga dapat digunakan sebagai pewarna alami jaringan tumbuhan karena mengandung antosianin, hal ini sesuai dengan pernyataan Sa'diyah (2015), bahwa pewarna alami berasal dari bagian tumbuhan tertentu yang mengandung antosianin. Antosianin yang terdapat pada ekstrak kulit buah manggis dapat menghasilkan warna merah, ungu dan biru, antosianin yang terkandung dalam kulit buah manggis dapat diekstraksi dengan metode sederhana yaitu maserasi yang merupakan metode ekstraksi tanpa pemanasan dimana hasilnya dipengaruhi oleh jenis pelarut serta waktu maserasi (Wijayanti et al., 2016). Jenis pelarut seperti etanol dan akuades biasa digunakan untuk maserasi zat warna, karena memiliki sifat polar yang sesuai dengan antosianin (Nida, 2013).

Merujuk hasil penelitian Saputri (2018), bahwa kulit ubi jalar ungu (Ipomoea batatas L.) yang diekstrak melalui metode maserasi dengan jenis pelarut asam sitrat $14 \%$ dan etanol $96 \%$ dengan lama perendaman masing-masing 24, 25 dan 26 jam mampu mewarnai jaringan batang tumbuhan krokot dengan baik, jaringan yang terwarnai yaitu epidermis, parenkin, xylem dan floem. Pelarut yang lebih efektif untuk proses ekstraksi adalah asam sitrat $14 \%$ karena warna yang dihasilkan pada preparat section batang krokot lebih cerah dibandingkan dengan pelarut etanol $96 \%$, sedangkan lama perendaman ekstraksi tidak menunjukkan perbedaan warna pada preparat. Samiyarsih et al. (2020) menyatakan bahwa keberhasilan proses pewarnaan jaringan tanaman ditentukan oleh karakteristik jaringan dan lama waktu perendaman. Berbagai modifikasi waktu pewarnaan telah dilakukan pada jaringan anatomi daun mangrove akibat pencemaran air (Samiyarsih et al., 2016), preparat ubi jalar yang diinokulasi penyakit (Samiyarsih et al., 2018), pada jaringan daun beberapa varietas tapak dara (Samiyarsih et al., 2019).
Krokot (Portulaca oleracea L.) oleh sebagian masyarakat Indonesia dianggap sebagai gulma, setelah mengetahui kandungan gizi dan manfaat untuk kesehatan tubuh, kini krokot banyak dibudidayakan (Imanuna et al., 2018). Krokot mengandung omega-3, asam lemak, vitamin A, vitamin C dan vitamin B kompleks (Simopoulos, 2004). Menurut Szalai et al. (2010) krokot mengandung banyak gizi sehingga dimanfaatkan sebagai sayuran dan obat herbal. Krokot salah satu sumber obat anti radang usus buntu karena mengandung zat yang mengatur metabolisme dan memiliki antioksidan tinggi (Anggarani et al., 2013). Peneliti ingin memanfaatkan krokot sebagai bahan penelitian sebagai preparat awetan untuk analisis pengamatan jaringan. Krokot memiliki batang berbentuk bulat berwarna coklat keunguan, daun tunggal, tebal berdaging, berbentuk bulat telur, permukaan atas berwarna hijau tua dan permukaan bawah berwarna merah tua, tangkai pendek dan bagian ujung bulat melekuk ke dalam (Hariana, 2015).

Berdasarkan latar belakang tersebut, maka dirumuskan permasalahan, yaitu apakah ekstrak kulit buah manggis mampu mewarnai jaringan daun dan batang krokot dan jenis pelarut apa dan berapa lama waktu perendaman ekstraksi yang optimal untuk menghasilkan ekstrak kulit buah manggis sehingga dapat mewarnai jaringan daun dan batang krokot dengan baik. Tujuan dari penelitian meliputi mengetahui kemampuan ekstrak kulit buah manggis dalam mewarnai jaringan daun dan batang krokot dan mengetahui jenis pelarut dan lama waktu perendaman ekstraksi yang optimal untuk menghasilkan ekstrak kulit buah manggis sehingga mampu mewarnai jaringan daun dan batang krokot dengan baik.

\section{METODE PENELITIAN}

Bahan yang digunakan pada penelitian ini adalah kulit buah manggis, daun dan batang krokot, etanol $96 \%$, asam sitrat $14 \%$, larutan fiksatif FAA, alkohol $70 \%$, alkohol $80 \%$ dan alkohol $96 \%$, etanol PA, xylol, parafin murni, akuades, gliserin, albumin dan entelan, sedangkan alat yang digunakan pada penelitian ini adalah blender, alumunium foil, batang pengaduk, saringan, silet, botol flakon, oven, cutter, holder, object glass, thermostat, staining jar, rotary microtom, cover glass, mikroskop, gelas arloji, beaker glass, gelas ukur, pipet tetes, pinset, kamera, alat tulis, kertas label, baki, bunsen dan tisu. Penelitian dilaksanakan di Laboratorium Struktur dan Perkembangan Tumbuhan Fakultas Biologi Unsoed Purwokerto pada bulan Juli-Agustus 2019.

Rancangan penelitian yang digunakan adalah Rancangan Acak Lengkap (RAL) dengan menggunakan 2 faktor, faktor 1 adalah jenis pelarut (P) dengan dua perlakuan yaitu : pelarut etanol $96 \%$ (P1) dan pelarut asam sitrat 14\% (P2) dan faktor 2 adalah lama perendaman (L) dengan tiga perlakuan 
yaitu : 26 jam (L1), 27 jam (L2) dan 28 jam (L3). Sehingga perlakuan penelitian berjumlah 6 kombinasi dan masing-masing perlakuan dilakukan 3 kali ulangan. Variabel bebas yaitu jenis pelarut dan lama perendaman. Variabel terikat yaitu jaringan daun dan batang krokot yang terwarnai oleh ekstrak kulit buah manggis. Parameter yang diamati yaitu kekontrasan warna dan kejelasan preparat daun dan batang krokot.

Penelitian dilakukan dua tahap, tahap pertama ekstraksi kulit buah manggis dengan menggunakan metode maserasi. Tahap kedua pembuatan preparat awetan dengan metode embedding untuk bagian daun dan metode non-embedding untuk bagian batang.

Ekstraksi dengan metode maserasi yang dimodifikasi (Basito, 2011)

Kulit buah manggis dibersihkan, dipotong kemudian dihaluskan menggunakan blender. $100 \mathrm{~g}$ bubuk kulit buah manggis direndam dengan $100 \mathrm{ml}$ etanol $96 \%$ dan $100 \mathrm{~g}$ bubuk kulit buah manggis direndam dengan $100 \mathrm{ml}$ t asam sitrat $14 \%$ dengan lama perendaman sesuai dengan perlakuan yaitu 26 jam, 27 jam dan 28 jam. Ditutup dengan aluminium foil, disimpan diruang tertutup dan sesekali diaduk dengan batang pengaduk kemudian disaring.

\section{Pengambilan sampel batang dan daun Krokot}

Sampel daun dan batang krokot diambil dari lingkungan Fakultas Biologi Unsoed Purwokerto.

\section{Preparasi awetan}

1) Preparasi awetan jaringan daun

Pembuatan preparat awetan irisan melintang daun krokot dilakukan dengan menggunakan metode embedding yang dimodifikasi (Sass, 1951). Preparat dibuat 3 macam : preparat dengan pewarna ekstrak kulit manggis, preparat dengan pewarna safranin sebagai pembanding, dan preparat tanpa pewarna sebagai kontrol.

2) Preparasi awetan jaringan batang

Pembuatan preparat awetan irisan melintang batang krokot dilakukan dengan menggunakan metode non-embedding yang dimodifikasi (Preece, 1959). Preparat dibuat 3 macam : preparat dengan pewarna ekstrak kulit manggis, preparat dengan pewarna safranin sebagai pembanding dan preparat tanpa diwarnai sebagai kontrol.

\section{Pengamatan Hasil Penelitian}

Kekontrasan dan kejelasan preparat diamati menggunakan mikroskop perbesaran 40x dan 100x, kemudian dibandingkan antara preparat yang diwarnai dengan pewarna alami ekstrak kulit buah manggis, preparat yang diwarnai dengan safranin dan preparat tanpa pewarnaan sebagai kontrol.

\section{Kekontrasan Preparat}

Kekontrasan diukur menggunakan color chart red menurut Martin (2009) pada Gambar 1. Kemudian diamati menggunakan indikator kekontrasan menurut Wahyuni (2015) yang dimodifikasi :

$$
\begin{array}{ll}
\text { a. }+ & \text { : Kurang kontras }(10 \%-20 \%) \\
\text { b. }++ & : \text { Kontras }(40 \%-60 \%) \\
\text { c. }+++ & : \text { Sangat kontras }(80 \%-100 \%)
\end{array}
$$
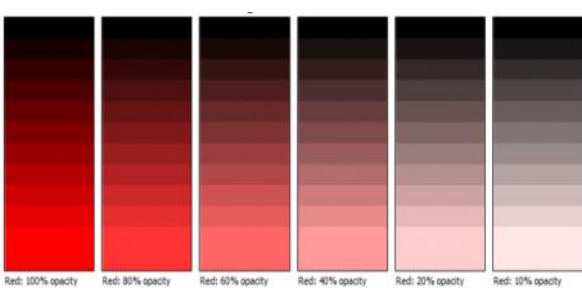

Gambar 1. Color Chart Red.

Sumber : www.stripgenerator.com.

\section{Kejelasan Preparat}

Kejelasan preparat diukur berdasarkan bagianbagian jaringan daun dan batang yang dapat teramati berdasarkan indikator kejelasan preparat menurut Wahyuni (2015) yang dimodifikasi :

+ : Kurang jelas, apabila bagian-bagian struktur jaringan kurang dapat dibedakan dengan jelas

++ : Jelas, apabila dapat mewarnai struktur jaringan dengan jelas sehingga bagian-bagian jaringan dapat dibedakan dengan jelas.

+++ : Sangat jelas, apabila dapat mewarnai struktur jaringan dengan sangat jelas sehingga bagian-bagian dapat dibedakan dengan sangat jelas.

\section{Analisis Data}

Data dianalisis secara deskriptif kualitatif meliputi kekontrasan dan kejelasan preparat berdasarkan indikator kekontrasan dan kejelasan preparat.

\section{HASIL DAN PEMBAHASAN}

Hasil penelitan kekontrasan dan kejelasan preparat awetan jaringan daun krokot dengan menggunaan ekstrak kulit buah manggis sebagai pewarna alami jaringan daun krokot dengan variasi perlakuan jenis pelarut yaitu pelarut etanol $96 \%$ dan pelarut asam sitrat $14 \%$ dan lama perendaman yaitu selama 26, 27 dan 28 jam diperoleh tingkat kekontrasan dan kejelasan jaringan yang berbeda seperti pada Tabel 1 .

Tabel 1. Kekontrasan dan kejelasan preparat awetan daun krokot

\begin{tabular}{lll}
\hline \multicolumn{1}{c}{ Perlakuan } & \multicolumn{1}{c}{ Kekontrasan } & Kejelasan \\
\hline P1L1 & $+(10 \%)$ & + \\
P1L2 & $+(20 \%)$ & ++ \\
P1L3 & $++(40 \%)$ & ++ \\
P2L1 & $++(60 \%)$ & +++ \\
P2L2 & $+++(80 \%)$ & +++ \\
P2L3 & $+++(100 \%)$ & +++ \\
\hline
\end{tabular}

Ket. : + : Kurang Kontras / Kurang jelas

++ : Kontras / Jelas

+++ : Sangat Kontras / Sangat Jelas 
Jenis pelarut asam sitrat $14 \% \quad(\mathrm{P} 2)$ menunjukkan kekontrasan dan kejelasan jaringan yang lebih baik dibandingkan pelarut etanol $96 \%$ (P1) (Tabel 1). Pewarna alami ekstrak kulit buah manggis dengan perlakuan asam sitrat $14 \%$ lebih mampu mewarnai jaringan daun krokot karena jaringan daun krokot lebih mampu menyerap warna ekstrak kulit manggis dengan perlakuan asam sitrat $14 \%$ dengan baik. Hal ini sesuai dengan pernyataan (Hermawati, 2015) bahwa asam sitrat merupakan pelarut yang bersifat polar dalam melarutkan antosianin menghasilkan konsentrasi yang tinggi dan lebih stabil. Lama perendaman 28 jam (L3) menunjukkan hasil yang paling baik dikarenakan lama perendaman berpengaruh terhadap hasil ekstraksi. Lebih lama waktu yang digunakan untuk maserasi maka akan melarutkan banyak zat warna, sehingga pewarna alami ekstrak kulit manggis mampu mewarnai jaringan daun krokot. Hal ini sesuai dengan hasil penelitian Sartono (2018), bahwa semakin lama waktu maserasi maka semakin banyak kontak antara bahan dan pelarut sehingga antosianin semakin banyak yang terlarut.

Perlakuan dengan menggunakan pelarut etanol 96\% dengan lama perendaman 26 jam (P1L1) menunjukkan preparat kurang kontras dikarenakan zat warna kurang terserap kedalam jaringan sehingga warna yang dihasilkan kurang terwarnai, dan untuk kejelasan preparat kurang jelas karena bagian-bagian jaringan tidak bisa dibedakan. Pelarut etanol 96\% dengan lama perendaman 27 jam (P1L2) menunjukkan preparat kurang kontras karena zat warna kurang mewarnai jaringan dan kejelasan preparat jelas karena jaringan dapat dibedakan. Pelarut etanol 96\% dengan lama perendaman 28 jam (P1L3) menunjukkan preparat yang kontras karena zat warna terserap dengan baik sehingga warna yang dihasilkan kontras dan kejelasan jaringan jelas sehingga dapat dibedakan bagian-bagiannya (Gambar 1).
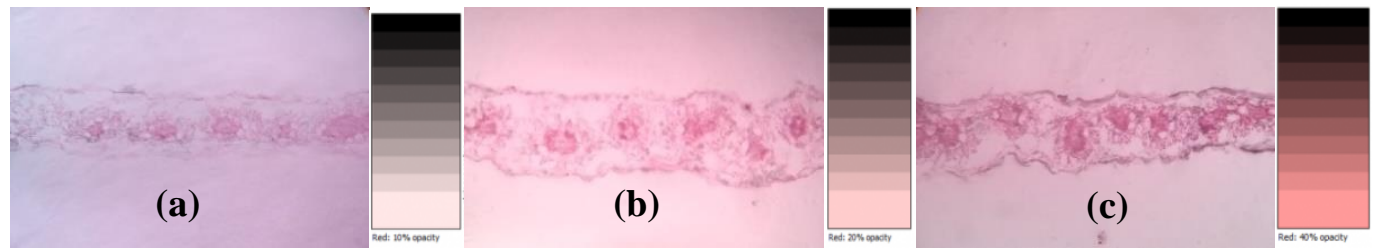

Gambar 1. Penampang melintang daun krokot perlakuan etanol 96\% perbesaran 40x. Keterangan : Perlakuan (a) P1L1 (b) P1L2 (c) P1L3

Perlakuan dengan menggunakan jenis pelarut asam sitrat $14 \%$ dengan lama perendaman 26 jam (P2L1) menunjukkan preparat yang kontras karena jaringan terwarnai dengan baik dan bagian-bagian jaringan sangat jelas untuk dibedakan. Pelarut asam sitrat 14\% dengan lama perendaman 27 jam (P2L2) menunjukkan preparat yang sangat kontras karena jaringan mampu menyerap zat warna dengan sangat baik sehingga warna yang dihasilkan berwarna merah, sangat kontras dan bagiab-bagian jaringan sangat jelas untuk dibedakan diantaranya bagian epidermis, berkas pengangkut dan parenkim. Pelarut asam sitrat $14 \%$ dengan lama perendaman 28 jam (P2L3) menunjukkan preparat paling baik yaitu sangat kontras dimana warna yang dihasilkan berwarna merah cerah dengan tingkat kekontrasan $100 \%$ dan kejelasan yang sangat jelas sehingga bagian-bagian antara jaringan dapat dibedakan diantaranya bagian epidermis, berkas pengangkut, bagian mesofil/parenkim dan epidermis bawah (Gambar 2).
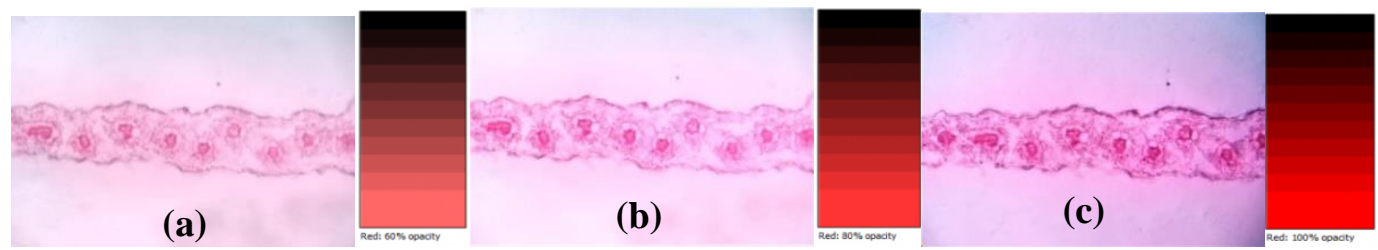

Gambar 2. Penampang melintang daun krokot perlakuan asam sitrat 14\% Perbesaran 40x. Keterangan : Perlakuan (a) P2L1 (b) P2L2 (c) P2L3

Perbandingan antara jaringan tanpa diwarnai, jaringan diwarnai dengan safranin dan jaringan diwarnai dengan pewarna alami ekstrak kulit manggis dengan perlakuan etanol $96 \%$ dan pewarna alami ekstrak kulit manggis perlakuan asam sitrat $14 \%$ menunjukkan kekontrasn dan kejelasan yang berbeda (Gambar 3). Jaringan daun krokot tanpa pewarnaan menunjukkan jaringan yang tidak kontras, jaringan tidak terwarnai dan jaringan tidak jelas. Jaringan kurang dapat dibedakan bagianbagiannya, yang dapat diamati adalah bagian epidermis dan berkas pengangkut saja, dan jaringan yang dihasilkan tampak transparan. Menurut Elayanti et al. (2017), preparat yang tanpa diwarnai akan menghasilkan jaringan yang transparan dan sulit untuk dibedakan antar jaringannya. Jaringan 
dengan menggunakan pewarna alami ekstrak kulit buah manggis dan jaringan dengan pewarna safranin memperlihatkan jaringan terwarnai merah kontras dan jelas bagian-bagian antar jaringannya. Hal ini sesuai dengan pernyataan Wahyuni (2008), bahwa jaringan yang diwarnai dapat memperjelas dan mempertajam berbagai elemen jaringan.

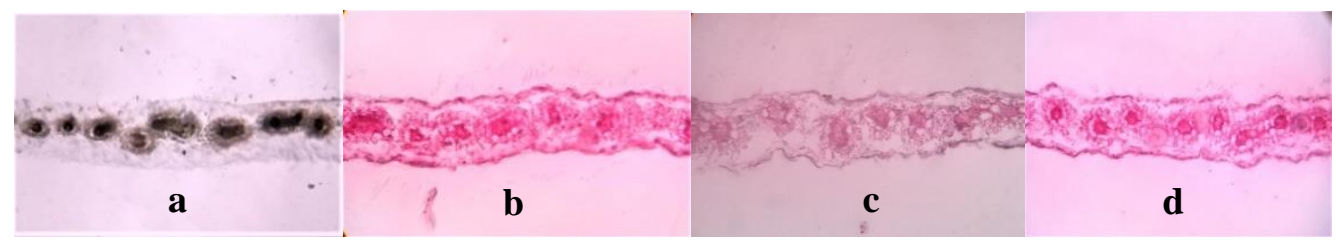

Gambar 3. Perbandingan penampang melintang daun krokot. Perbesaran 40x.

Keterangan : (a)Tanpa pewarna (b)Pewarna Safranin (c)Pewarna ekstrak kulit manggis perlakuan etanol $96 \%$ (d)Pewarna ekstrak kulit manggis perlakuan asam sitrat $14 \%$

Pewarna alami dari ekstrak kulit buah manggis dapat mewarnai jaringan daun krokot, dimana jaringan daun berwarna merah kontras dan bagianbagian jaringan dapat dibedakan. Jaringan yang teramati yaitu epidermis atas, mesofil/parenkim, berkas pengangkut dan epidermis bawah (Gambar 4). Penyerapan warna pada setiap jaringan berbeda, misalnya berkas pengangkut yang merupakan sel yang mengalami penebalan sekunder (lignifikasi) nampak berwarna merah cerah dibandingkan bagian parenkim yang berwarna merah tipis (Gambar 4). Hal ini sesuai dengan pernyataan Sa'diyah (2015) bahwa parenkim merupakan sel berdinding tipis dan tidak mengalami lignifikasi (penebalan sekunder) sehingga mempengaruhi kemampuan penyerapan zat warna yang kurang optimal.

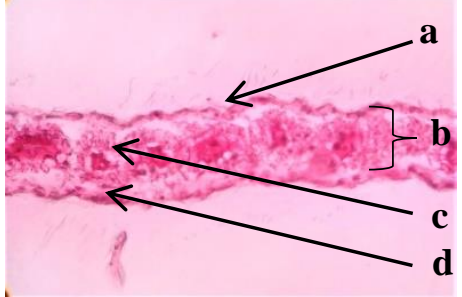

Gambar 4. Penampang melintang daun krokot bagian-bagiannya. Perbesaran 40x.
Keterangan
(a) Epidermis atas
Mesofil/parenkim
(c) Berkas pengangkut
Epidermis bawah

Terwarnainya jaringan daun krokot oleh pewarna alami ekstrak kulit buah manggis dikarenakan adanya reaksi karema muatan ion yang berbeda antara muatan ion zat warna ekstrak kulit manggis dan muatan ion jaringan daun krokot. Reaksi ikatan elektrostatik antara muatan ion zat warna dengan bagian sel yang berbeda muatan menyebabkan terwarnainya jaringan menjadi merah (Nurwanti et al., 2013). Antosianin yang terkandung dalam ekstrak kulit buah manggis memiliki $\mathrm{pH}$ asam yang mampu mewarnai dinding sel yang memiliki pH basa, ion positif pada zat warna antosianin akan terlepas dan berikatan kovalen dengan ion negatif yang terdapat pada dinding sel jaringan (Hamid \& Muhlis, 2005).

Hasil penelitan kekontrasan dan kejelasan preparat awetan jaringan batang krokot dengan menggunaan ekstrak kulit buah manggis sebagai pewarna alami jaringan batang krokot dengan variasi perlakuan jenis pelarut yaitu pelarut etanol $96 \%$ dan pelarut asam sitrat $14 \%$ dan lama perendaman yaitu selama 26, 27 dan 28 jam diperoleh tingkat kekontrasan dan kejelasan jaringan yang berbeda seperti pada Tabel 2 .

Tabel 2. Kekontrasan dan kejelasan preparat awetan batang krokot

\begin{tabular}{ccc}
\hline Perlakuan & Kekontrasan & Kejelasan \\
\hline P1L1 & $+(20 \%)$ & ++ \\
P1L2 & $++(40 \%)$ & ++ \\
P1L3 & $++(60 \%)$ & ++ \\
P2L1 & $++(60 \%)$ & +++ \\
P2L2 & $+++(80 \%)$ & +++ \\
P2L3 & $+++(100 \%)$ & +++ \\
\hline
\end{tabular}

Ket. : + : Kurang Kontras / Kurang jelas

++ : Kontras / Jelas

+++ : Sangat Kontras / Sangat Jelas

Pewarna alami ekstrak kulit buah manggis dengan perlakuan pelarut asam sitrat $14 \%$ lebih efektif dalam mewarnai jaringan batang krokot dibandingkan dengan pewarna alami ekstrak kulit buah manggis dengan perlakuan etanol 96\% (Tabel 2). Hal ini sesuai dengan penelitian Sartono (2018), bahwa asam sitrat memiliki keasaman yang sangat stabil sehingga keadaan asam ini akan memecahkan banyak dinding sel vakuola yang menyebabkan warna jaringan yang dihasilkan menjadi kontras terwarnai. Perlakuan dengan lama perendaman selama 28 jam menunjukkan hasil yang paling baik, semakin lama waktu perendaman pada proses maserasi maka akan semakin banyak antosianin yang diperoleh sehingga jaringan batang krokot semakin kontras dan jelas. Hal ini sesuai dengan hasil penelitian Armanzah \& Hendrawati (2016), bahwa semakin lama waktu maserasi maka semakin 
lama interaksi antara bahan dengan pelarut, sehingga tinggi kadar antosianin yang diperoleh. Kadar antosianin yang tinggi mnyebabkan semakin efektif dalam mewarnai jaringan tumbuhan.

Pewarna alami ekstrak kulit buah manggis dengan perlakuan menggunakan pelarut etanol 96\% dengan lama perendaman 26 jam (P1L1) menunjukkan preparat batang krokot kurang kontras dengan nilai kekontrasan $20 \%$, namun jaringan batang krokot jelas sehingga dapat dibedakan bagian-bagian jaringannya. Pewarna alami ekstrak kulit buah manggis dengan perlakuan menggunakan pelarut etanol 96\% dengan lama perendaman 27 jam (P1L2) menunjukkan nilai kekontrasan sebesar $40 \%$ atau jaringan batang krokot kontras terwarnai dengan kejelasan jaringan batang krokot yang jelas dimana bagian-bagian jaringan batang krokot dapat dibedakan. Pewarna alami dengan perlakuan jenis pelarut etanol $96 \%$ dengan lama perendaman 28 jam (P1L3) menunjukkan kekontrasan jaringan batang krokot dengan nilai kekontrasan sebesar $60 \%$ kontras, dan kejelasan jaringan jelas dimana bagianbagian jaringannya dapat dibedakan diantaranya bagian epidermis. (Gambar 5).
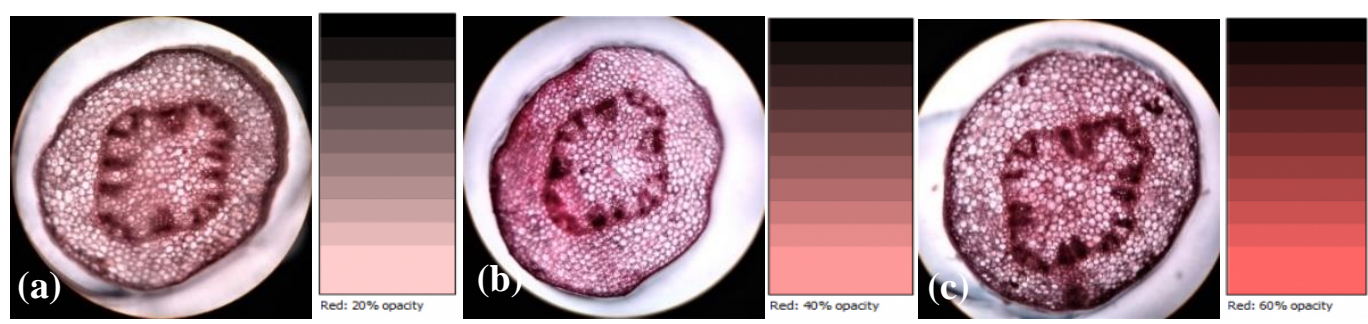

Gambar 5. Penampang melintang batang krokot perlakuan etanol 96\% perbesaran 40x.

Keterangan : Perlakuan (a) P1L1 (b) P1L2 (c) P1L3

Pewarna alami ekstrak kulit buah manggis dengan perlakuan pelarut asam sitrat $14 \%$ dengan lama perendaman 26 jam (P2L1) menunjukkan kekontrasan jaringan batang krokot sebesar $60 \%$ dan kejelasan jaringan batang krokot jelas sehingga bagian-bagian jaringan batang krokot dapat dibedakan dengan jelas. Pewarna ekstrak kulit buah manggis dengan perlakuan pelarut asam sitrat $14 \%$ dengan lama perendaman 27 jam (P2L2) menunjukkan nilai kekontrasan jaringan sebesar $80 \%$ atau jaringan batang krokot sangat kontras dan jaringan sangat jelas sehingga jaringan dapat dibedakan bagian-bagiannya dengan sangat jelas. Diantaranya bagian epidermis, korteks dan berkas pengangkut. Pewarna alami ekstrak kulit buah manggis dengan perlakuan pelarut asam sitrat $14 \%$ dengan lama perendaman 28 jam (P2L3) menunjukkan preparat jaringan batang krokot yang paling baik yaitu dengan nilai kekontrasan $100 \%$ atau jaringan batang krokot sangat kontras dengan kejelasan bagian-bagian yang dapat dibedakan dengan sangat jelas (Gambar 6).

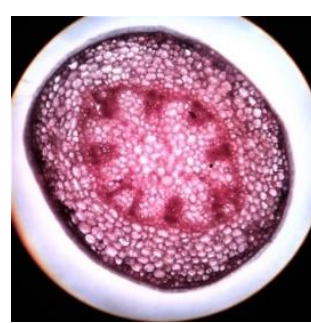

(a)

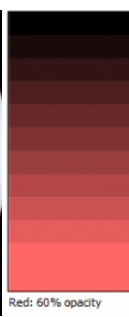

Red: $60 \%$ opsocty

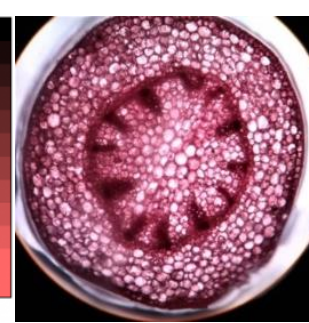

(b)

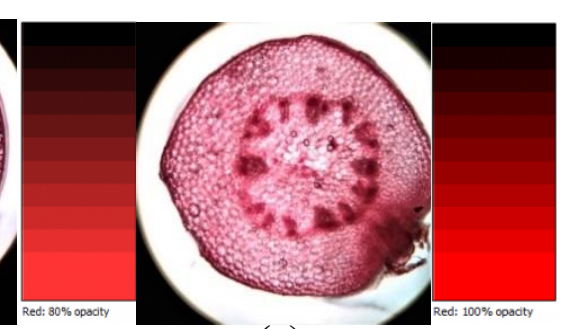

(c)

Gambar 6. Penampang melintang batang krokot perlakuan asam sitrat 14\% perbesaran 40x. Keterangan : Perlakuan (a) P2L1 (b) P2L2 (c) P2L3.

Perbandingan antara jaringan batang tanpa diwarnai dan jaringan batang yang diwarnai dengan pewarna, baik itu pewarna safranin ataupun pewarna alami ekstrak kulit buah manggis dengan perlakuan etanol $96 \%$ dan asam sitrat $14 \%$, menunjukkan jaringan batang yang diberikan pewarna menghasilkan kekontrasan dan kejelasan pada jaringan tersebut (Gambar 7). Hal ini sesuai dengan pernyatan Indasari et al. (2013), bahwa proses pemberian warna pada jaringan akan membuat jaringan itu nampak berwarna kontras sehingga mudah diamati. 


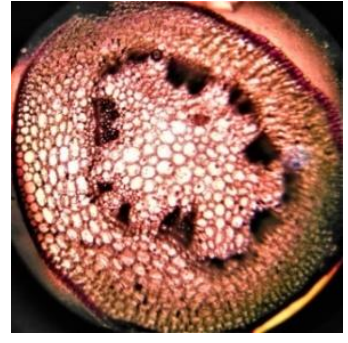

$\mathbf{a}$

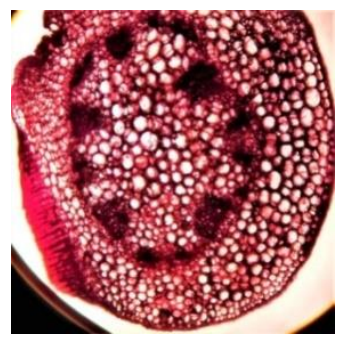

b

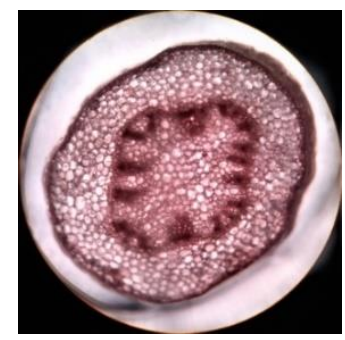

c

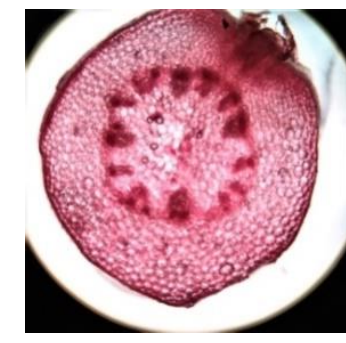

d

Gambar 7. Perbandingan penampang melintang batang krokot perbesaran 40x.

Keterangan : (a)Tanpa pewarna (b)Pewarna Safranin (c)Pewarna ekstrak kulit manggis perlakuan etanol 96\% (d)Pewarna ekstrak kulit manggis perlakuan asam sitrat $14 \%$

Pewarna alami dari ekstrak kulit buah manggis dapat mewarnai jaringan batang krokot, dimana jaringan batang berwarna merah kontras dan bagianbagian jaringan dapat dibedakan. Jaringan yang teramati yaitu epidermis, korteks dan berkas pengangkut (Gambar 8). Molekul antosianin ekstrak kulit buah manggis berikatan dengan molekul yang ada pada jaringan batang krokot sehingga jaringan nampak berwarna merah. Hal ini sesuai dengan pernyataan Indasari et al. (2013) bahwa warna yang tampak pada jaringan merupakan hasil ikatan molekul antara zat warna dengan jaringan yang diwarnai.

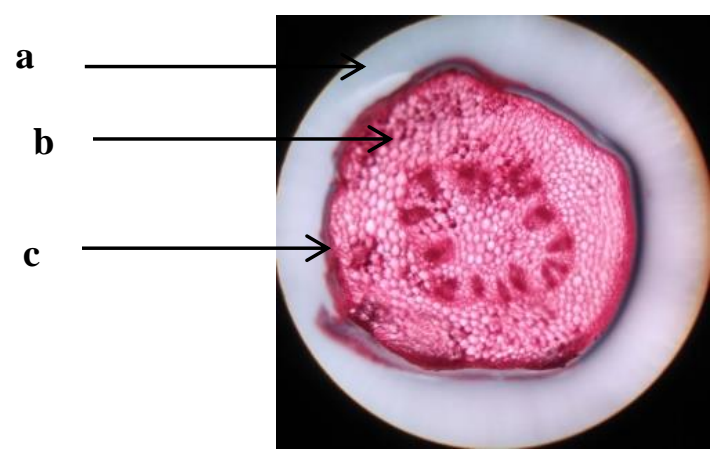

Gambar 8. Penampang Melintang Batang Krokot Bagian-bagiannya Perbesaran 40x.

Keterangan : (a) Epidermis (b) Korteks (c) Berkas Pengangkut

Penggunaan dua jenis pelarut yang berbeda dalam proses ekstraksi yaitu untuk membandingkan kemampuan dalam mengekstraksi antosianin dalam kulit buah manggis. Pelarut etanol bersifat polar sehingga mudah melarutkan zat warna antosianin yang bersifat polar juga. Asam sitrat digunakan untuk ekstraksi antosianin karena antosianin tidak stabil dalam larutan basa atau netral. Pada Gambar 9 menunjukkan perbedaaan warna ekstraksi kulit buah manggis dengan pelarut etanol $96 \%$ dan asam sitrat $14 \%$, ekstraksi dengan pelarut asam sitrat $14 \%$ lebih berwarna merah pekat sedangkan ekstraksi dengan pelarut etanol $96 \%$ berwarna merah bening. lama perendaman selama 26, 27 dan 28 jam menunjukkan perbedaan warna ekstraksi kulit buah manggis, semakin lama perendaman maserasi maka warna yang dihasilkan semakin merah, hal ini sesuai dengan pernyataan Wijayanti et al. (2016) bahwa penambahan waktu maserasi akan meningkatakan kadar antosianin yang diperoleh dari kulit buah manggis.

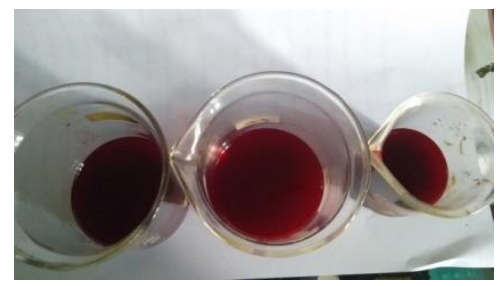

$\mathbf{a}$

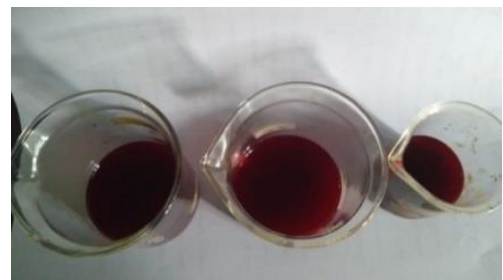

b

Gambar 9. Hasil maserasi ekstrak kulit buah manggis.

Keterangan : (a) pelarut etanol $96 \%$ (b) pelarut asam sitrat $14 \%$ 
Kulit buah manggis mengandung banyak antosianin sehingga dapat dimanfaatkan sebagai pewarna alami jaringan daun dan batang krokot. Jenis pelarut dan lama perendaman maserasi yang berbeda berpengaruh terhadap penyerapan warna jaringan daun dan batang krokot. Variasi perlakuan jenis pelarut etanol $96 \%$ dan asam sitrat $14 \%$ dan lama perendaman yang berbeda menunjukkan hasil yang berbeda. Perlakuan dengan menggunakan pelarut asam sitrat menunjukkan hasil yang lebih baik dibandingkan pelarut etanol 96\%. Kualitas preparat yang dihasilkan baik sehingga tidak jauh berbeda dengan jaringan yang diwarnai oleh pewarna safranin. Keduanya memiliki warna yang kontras dan bagian-bagian jaringan yang jelas. Ekstrak kulit buah manggis dengan pelarut asam sitrat $14 \%$ dengan lama perendaman 28 jam memiliki kekontrasan dan kejelasan yang paling optimal sebagai pewarna alami untuk jaringan sebagai pengganti pewarna sintetis.

\section{SIMPULAN}

Berdasarkan hasil penelitian dapat disimpulkan bahwa ekstrak kulit buah manggis memiliki kemampuan dalam mewarnai jaringan daun dan batang krokot. Jenis pelarut asam sitrat $14 \%$ dengan lama perendaman selama 28 jam merupakan yang optimal dalam menghasilkan ekstrak kulit buah manggis sehingga mampu mewarnai jaringan daun dan batang krokot.

\section{DAFTAR REFERENSI}

Aji, A., Meriatna \& Ferani, A.S. 2013. Pembuatan Pewarna Makanan dari Kulit Buah Manggis dengan Proses Ektraksi. Jurnal Teknologi Kimia Unimal, 2(2), pp.1-15.

Anam, C., Mahmudati, N. \& Hudha, A.M. 2016. Ekstrak Kulit Buah Naga Merah (Hylocereus polyrhizus) sebagai Pewarna Alami Preparat Section Tumbuhan Sirsak (Annona muricata). Prosiding Seminar Nasioanl III. Malang : FKIP dan PSLK Universitas Muhammadiyah Malang. pp. 812-818.

Anggarani, D.N., Kartika, D \& Novitasari, D.A. 2012. "Table Kroasia" Tablet krokot berkhasiat, inovasi effervescent dari tanaman krokot (Portulaca oleracea L.) sebagai alternatif minuman bersuplemen bagi penderita radang usus buntu. Jurnal Ilmiah Mahasiswa, 2(2), pp.91-96.

Astuti, R.E. 2016. Penggunaan Rimpang Temulawak (Curcuma zanthorrhiza L.) sebagai Pewarna Preparat Maserasi Batang Iler (Coleus scutellarioides L.) sebagai Media Pembelajaran Biologi. Skripsi. Malang : Fakultas Keguruan dan Ilmu
Pendidikan Universitas Muhammadiyah Malang. pp.1-20.

Basito. 2011. Efektivitas Penambahan Etanol 95\% dengan Variasi Asam dalam Proses Ekstraksi Pigmen Antosianin Kulit Manggis (Garcinia mangostana L.). jurnal Tekonlogi Hasil Pertanian, 4(2), pp.84-93.

Dewi, A.R., Purwanti, E. \& Nurwidodo. 2017. Kualitas Preparat Section Organ Tanaman Srikaya (Annona squamosa) dengan Pewarna Alami Filtrat Daun Jati Muda (Tectona grandis) sebagai Sumber Belajar Biologi SMA. Prosiding Seminar Nasional Tahun 2017. Malang : FKIP dan PSLK Universitas Muhammadiyah Malang. pp. 95-105.

Dewi, R.K. 2010. Pengamatan Inti Sel Ujung Akar Allium cepa menggunakan Pewarna Alternatif Buah Gendula-gendulu (Breynia sp) dan Perasan Rimpang Kunyit (Curcuma domestica). Skripsi. Surakarta : Fakultas Keguruan dan Ilmu Pendidikan Universitas Muhammadiyah Surakarta. pp.1-15.

Elayanti, L. 2018. Pemanfaatan Ekstrak Daun Jati Muda sebagai Pewarna Alami dengan Lama Perendaman dan Jenis Pelarut yang Berbeda pada Preparat Batang Cabai. Skripsi. Surakarta : Fakultas Keguruan dan Ilmu Pendidikan Universitas Muhammadiyah Surakarta. pp.1-14.

Farida, R \& Nisa, F.C. 2015. Ekstraksi Antosianin Limbah Kulit Manggis Metode Microwave Assisted Extraction (Lama Ekstraksi dan Rasio Bahan : Pelarut). Jurnal Pangan dan Agroindustri, 3(2), pp.362-373.

Gresby, A. 2013. Pemanfaatan Filtrat Daun Jati Muda (Tectona grandis) sebagai Bahan Pewarna Alternatif Pembuatan Preparat Maserasi Batang Cincau Rambat (Cyclea barbata). Skripsi. Malang : Fakultas Keguruan dan Ilmu Pendidikan Universitas Muhammadiyah Malang. pp.1-13.

Hariana, 2015. 262 .Tumbuhan Obat dan Khasiatnya. Jakarta : Penebar Swadaya

Imanuna, M., Widodo, M.W \& Tako, Y.E. 2018. Riko Lara sebagai alternatif pencegahan penyakit kardiovaskuler di Desa Karangwidoro Kabupaten Malang. Jurnal Karinov, 1(2), pp.1-6.

Martin \& Manoli. 2009. Advanced Color Chart Red. Di akses pada 3 Oktober 2019 www.stripgenerator.com

Nida, E.H., Melly, N., \& Syarifah, R. 2013. Kandungan Antosianin dan Aktivitas 
Antioksidan Ubi Jalar Ungu Segar dan Produk Olahannya. Jurnal Agritech, 33(3), pp.296-302.

Nurwanti, M., Budiono, J.D. \& Pratiwi, P.R. 2013. Pemanfaatan Filtrat Daun Muda Jati sebagai Bahan Pewarna Alternatif dalam Pembuatan Preparat Jaringan Tumbuhan. BioEdu, 2 Januari. pp.73-76.

Preece, A. 1959. A Manual For Histologic Technicians. Boston : Brown and Company.

Puspitasari, M.L., Wulansari, T.V., Widyaningsih, T.D., Maligan, J.Y \& Nugrahini, N.I.P. 2016. Aktivitas Antioksidn dan Suplemen Herbal Daun Sirsak (Annona muricata L.) dan Kulit Manggis (Garcinia mangostana L.). Jurnal Pangan dan Agroindustri, 4(1), pp.283-290.

Rubiyanti, R., Susilawati, Y \& Muchtaridi, M. 2014. Potensi Ekonomi Dan Manfaat Kandungan Alfa-Mangostin Serta Gartanin Dalam Kulit Buah Manggis (Garcinia mangostana Linn). Farmaka, 15(1), pp.15-25.

Sa'diyah, A.R. 2015. Penggunaan Filtrat Kunyit (Curcuma domestica val.) sebagai Pewarna Alternatif Jaringan Tumbuhan pada Tanaman Melinjo (Gnetum gnemon). BioEdu, 1 Januari. pp.365-369.

Samiyarsih, S., Brata, T., \& Juwarno. 2016. Karakter anatomi daun tumbuhan mangrove akibat pencemaran di hutan mangrove Kabupaten Cilacap. Biosfera 33(1), pp. 31-36.

Fitrianto N, Azizah E, Herawati W, Rochmatino. 2020. Anatomical profile and genetic variability of sweet potato (Ipomoea batatas) cultivars in Banyumas, Central Java, based on RAPD markers. Biodiversitas 21(4), pp. 1755-1766.

, Juwarno, Muljowati JS. 2018. The structural resistance's anatomy of sweet potato leaves to fungal pathogen Sphaceloma batatas. Biosaintifika 10(1), pp.131-137.

Naipospos, N., \& Palupi, D. 2019. Variability of Catharanthus roseus based on morphological and anatomical characters, and chlorophyll contents. Biodiversitas, 20(10), pp. 2986-2993.

Saputri, I.D. 2018. Pemanfaatan Ekstrak Kulit Ubi Jalar Ungu sebagai Pewarna Alami Preparat Section Batang Tumbuhan Krokot (Portulaca oleracea). Skripsi. Surakarta : Fakultas Keguruan dan Ilmu Pendidikan
Universitas Muhammadiyah Surakarta. pp.114.

Sartono, I.D. 2018. Pemanfaatan Ekstrak Kulit Buah Naga Super Merah sebagai Pewarna Alami Preparat Section Jaringan Tumbuhan Rumput Teki (Cyperus rotundus). Skripsi. Surakarta : Fakultas Keguruan dan Ilmu Pendidikan Universitas Muhammadiyah Surakarta. pp.110.

Sass, J.E. 1951. Botanical Microtechnique $3^{\text {rd }}$ Edition. Lowa : The Lowa State Collage Press.

Simopoulos, A., 2004. Omega-3 fatty acids in inflammation and autoimmune disease. Journal Am Clin Nutr, 21,pp. 495-505.

Szalai, G.N., Dai \& Avionam, S. 2010. Effect of nitrogen source in fertilizing solution on nutrional quality of three members of the Portulaca oleracea agregate. Journal science food agriculture, 90(12), pp.2039-2045.

Wahyuni, S. 2015. Identifikasi Preparat Gosok Tulang (Bone) Berdasarkan Teknik Pewarnaan. Prosiding Seminar Nasioanal Pendidikan Biologi 2015. Malang : Prodi Pendidikan Biologi FKIP Universitas Muahammadiyah Malang. pp. 657-666.

Wijayanti, N.P.A.D., Elayanti, L.P.M.K., Astuti, K.W \& Fitri, N.P.E. 2016. Optimasi Waktu Maserasi untuk Manggis (Garcinia mangostana L.) Rind Menggunakan Pelarut Etil Asetat. Jurnal Farmasi dan Ilmu Kefarmasian Indonesia, 3(1), pp.12-16. 